\title{
ФОРМЫ ДИСКУРСИВНОЙ ДАННОСТИ В ТВОРЧЕСТВЕ РАБОТНИКОВ ГУБЕРНСКИХ УЧЕНЫХ АРХИВНЫХ КОМИССИЙ
}

Данная статья рассматривает деятельность губернских ученых архивных комиссий, зародившихся в конце XIX - начале XX веков, как сложную, многослойную, многоуровневую систему. Вторая половина XIX начало XX веков характеризуется как время формирования краеведения как сложносоставного интегративного социокультурного феномена. Центральное место в этот период занимало локальное интеллектуальное сообщество краеведческой направленности, которое было представлено архивными комиссиями, привлекательными в первую очередь тем, что они являются феноменом, отражающим одновременно научно-организационное, научно-коммуникативное и социокультурное пространство. Ведь комиссии формировали культурную жизнь и облик региона, пытались сохранить мало изученный ранее, практически потерянный исторический культурный потенциал.

Актуальность изучения этой проблемы возрастает и в силу того, что история архивных комиссий, архивного дела регионов до сих пор малоизучена. Несмотря на то что различенные аспекты темы так или иначе освеща- лись в научной литературе, в большинстве своем они носят характер отчетов, обзоров деятельности комиссии Рассмотрение же дискурсивной деятельности комиссий, характеристика их дискурсивных формаций представляются весьма плодотворными, ведь дискурсивная деятельность неразрывно связана с переработкой информации и представлением знаний, а также имеет свои особенности, так как предполагает особый ракурс восприятия мира и его познания.

Многофункциональность комиссий изначально определялась задачами и способами их реализации, интеллектуальной практикой. Данный факт дает основание для изучения дискурсивной деятельности архивных комиссий, в рамках которой нами описаны дискурсивные формации текстового поля комиссий как специфические принципы организации текста, представленные институциональными дискурсами (научный, педагогический, юридический, публицистический).

Ключевые слова: дискурс, дискурсивные формации, научный, педагогический, юридический, публицистический дискурс.

\section{A. Minina}

\section{FORMS OF DISCURSIVE ENTITY IN THE WORK OF EMPLOYEES OF PROVINCIAL SCIENTIFIC ARCHIVAL COMMISSIONS}

This article considers the activity of provincial scientists of archival commissions, which originated in the late XIX - early $X X$ centuries, as a complex, multi-layer, multi-level system. The second half of the XIX - early $X X$ centuries is characterized as the time of formation of local history as a complex integrative socio-cultural phenomenon. The central place in this period was occupied by the local intellectual community of local lore orientation, which was represented by archival commissions, which are attractive primarily because they are a phenomenon that reflects both scientific-organizational, scientific-communicative and socio-cultural space. After all, the commissions formed the cultural life and image of the region, tried to preserve the little studied earlier, almost lost historical cultural potential.

The relevance of the study of this problem increases due to the fact that the history of archival commissions, archival affairs of the regions is still poorly understood. Despite the fact that various aspects of the topic were covered in one way or another in the scientific literature, most of them are in

Согласно определению, данному Е. Г. Малышевой и основанному на подходе Г. Н. Манаенко [6], дискурс - «процесс тематически обусловлен- the nature of reports, reviews of the commission's activities The consideration of the discursive activities of the commissions, the characteristics of their discursive formations are very fruitful, because the discursive activity is inextricably linked with the processing of information and the presentation of knowledge, and also has its own characteristics, as it involves a special perspective of the perception of the world and its knowledge.

The versatility of the commissions was initially determined by the tasks and methods of their implementation, intellectual practice. This fact provides the basis for the study of the discursive activity of archival commissions, in which we describe the discursive formations of the text field of commissions as specific principles of the text organization represented by institutional discourses (scientific, pedagogical, legal, journalistic).

Key words: discourse, discursive formations, scientific, pedagogical, legal, journalistic discourse.

ного общения, детерминированного социально-историческими условиями, специфика которого отражается в совокупности текстов (в широком - 
семиотическом - понимании этого термина), характеризуемых концептуальным, речежанровым и прагмастилистическим своеобразием» [5, с. 90].

Как информационная конструкция дискурс представляет собой «хранилище разных видов знаний» [10, с. 72]. Вместе с этим дискурсивные формации являются спецификацией этих знаний в ходе их употребления. По мнению О. Г. Ревзиной, дискурсивные формации могут соединяться между собой, «частично совпадая по коммуникативным и когнитивным признакам, по используемым жанрам» [10, с. 68].

Дискурсивные формации текстового поля сотрудников губернских ученых архивных комиссий (далее - ГУАК) - это сложная, многослойная, многоуровневая, многофункциональная система текстов в силу того, что интеллектуальное наследие работников ГУАК дореволюционной России по своей широте и разносторонности не имеет аналогов в предшествующие и последующие периоды развития региональной научной мысли.

При характеристике деятельности ГУАК чаще всего акцентируется внимание на слове «архивные». Однако сами работники комиссий особо выделяли слово «ученые». Согласно «Положению об исторических архивах и учёных архивных комиссиях» (далее по тексту - Положение) 1884 года комиссии по своей инициативе могли «включать в круг своих занятий разыскание, описание и объяснение всяких других памятников старины» [9, с. 663$]$

В 1895 г. председатель Симбирской ГУАК В. Н. Поливанов назвал комиссию учреждением, «преследующим научные цели», и, говоря о важности архивной работы, видел задачей комиссии «занятия научные». Председатель Рязанской ГУАК С. Д. Яхонтов в 1909 г. говорил, что комиссия давно перестала быть только архивным предприятием, она делает науку. Член Саратовской ГУАК С. А. Харизоменов выражался еще более определенно, считая, что комиссия как учреждение областное «становится могучим орудием для популяризации науки, для объединения ее с жизнью и обществом» $[12$, с. 296].

Интересно также, что члены ГУАК определяли цели, преследуемые ими, как научно-воспиmательные, поскольку деятельность обществ заключалась не только в «изучении старины, собирании и сбережении разного рода памятников древности. Печатая в своих изданиях исторические материалы и исследования, устраивая публичные лекции, публичные заседания, открывая свои музеи для обозрения богатых коллекций, иллюстрирующих ее труды, комиссия участвует в великой просветительской задаче народного самопознания» [8, с. 7].

Развернув широкую научно-исследовательскую и просветительскую деятельность, ГУАК удалось продуцировать тексты, охватывающие разнообразные сферы исследовательской деятельности, порождающие многочисленные дискурсивные формации, то есть закономерности между высказываниями, которые посвящены единой тематике.
Дискурсивная деятельность сотрудников ГУАК представлена такими институциональными дискурсами, как научный, публицистический, педагогический, юридический. В рамках данных дискурсов нами были выявлены формы дискурсивной данности путем выделения структурообразующих уровней каждого из перечисленных видов дискурса

І. Сотрудники ГУАК - авторы многочисленных научных исследований различной дисциплинарной направленности.

\section{1. Архивное дело}

Следуя Положению, государство поставило перед ГУАК задачи разбора архивных документов, выделения те из них, которые представляли интерес в научном отношении для передачи их на хранение в создаваемые исторические архивы.

Таким образом, главным направлением деятельности ГУАК стало сохранение исторических материалов, приведение их в порядок и научная обработка.

Все это реализовалось в выполнении ряда практических, теоретических и методических задач:

а) спасение от гибели многих ценных дореволюционных архивов регионов;

б) исторические обзоры деятельности ГУАК (Халиппа И. Н. «Общий обзор әлавнейщих правительственных архивов города Кишинева, с очерком деятельности бывиих комиссий по разборке этих архивов»; Шуцкий $M$. "Mои впечатления, связанные со съездом представителей УАК» и другие);

в) обоснование ценности изучения региональных архивов (Савелов Л.М. « Что такое УАК, чmо она должна сделать и что может сделать?»; Вертоградов $\mathrm{U}$. "K вопросу о задачах ГУАК»; Прозрителев Г. Н. «Великое значение наших архивов» и другие);

г) создание методических разработок, направленных на обеспечение сохранности важных архивных источников (Прозрителев Г. Н. «Необходимо охранять памятники прошлого»; Малченко В. С. "Один из способов разборки архивов» и другие);

д) создание описей архивов различных губернских и уездных учреждений, фамильных и частных архивов (Халиппа И. Н. «Коллекция старинных документов из фамильного архива госпожи З. Ф. Донич, урожденной Карп-Руссо»; Добронравов Г. Н. «Дела Владимирского Губернского Правления, поступившие в архив ВУАК»; Загорский М. В. "Разбор и описание дел Переславского Духовного Правления» и другие).

\section{2. Исторические изыскания}

Спасенные и разработанные архивы оказались ценным материалом для последующего исследования исторического прошлого регионов. Исторические исследования ГУАК адресовались широкому кругу читателей и, по словам Колесниковой М. Е., «носили характер исследованияочерка и были научно-популярными, доступными для понимания простым людям» [2, с. 330].

Заслуги ГУАК в изучении и описании истории регионов трудно переоценить, сотрудникам при- 
надлежат работы, посвященные разным исследовательским областям:

а) общие исторические данные о регионе (Хaлиппа И. Н. «Материалы для истории Кишинева в XVI-XVII веках»: Рыпинский Г. Н. «Материаль для истории Владимирской губернии»; Быков Н. "Древний край Южного Приднепровья. Исторический этюд»; Прозрителев Г. Н. «Из истории города Ставрополя» и другие);

б)историязаселениярегиона(ПрозрителевГ.Н «Первые русские поселения на Северном Кавказе и в нынешней Ставропольской губернии»; Марков Е. Л. «Древние татарские иляхи Воронежской губернии», Синявский А. "К истории землевладения в Екатеринославщине» и другие);

в) история культурной жизни региона (Прозрителев Г. Н. «Городская хроника: Театр»; Данилов В. «Из проилого Екатеринославского театра»; Снежневский В. И. "Старый нижегородский театр» и другие);

г) история религиозных памятников и направлений (Щеглов Д. В. "Измаильские монастыри»; Добронравов В. Г. «Из истории молоканства о Владимирской епархии»; Минх А. Н. «Быт духовенства Саратовского края в XVIII и начале XIX столетий» и другие);

д) история образовательной деятельности (Тарасов П. Д. "Первые 15 лет деятельности Екатерининского института», Киреев П. Л. "Из истории Тамбовского сельского Покровского народного училища» и другие);

е) история различных региональных учреждений (Павловский И. Ф. «Кременчугская фрабрика сукноделия для евреев в начале XIX века», Попов И. «К истории казенных заводов» и другие)

Таким образом, благодаря ГУАК, по мнению Л. В. Чекурина, «изучение истории отдельных регионов значительно продвинулось вперед как в количественном, так и в качественном отношении» $[14$, с. 85$]$.

\section{3. Археология}

Значительное место в краеведческих изысканиях архивные комиссии уделили изучению древнейшего, “доисторического» периода в летописи своих областей. Главным источником информации о нем были археологические раскопки, причем сотрудники комиссий не ограничивались «только описанием добытого раскопками эмпирического материала», но во многих работах сделали попытки теоретического осмысления «экономического и общественного быта наших предков» $[11$, c. 11].

По словам А. Л. Монгайт, несмотря на «достаточную долю любительства, слабый контроль и недостаток средств, археологические исследования ГУАК привели к важным открытиям» [7, с. 20]

В рамках археологического направления исследований ГУАК занимались:

а) проведением раскопок (Фадеев А. Д. «О раскопках в Острогожском и Бобровском уездах», Мартинович А. Д. «Раскопки курганов вблизи Хазарского городища в 1906 году» и другие);

б) разработкой методологических указаний по проведению археологических изысканий (Тру- нов М. П. «К организации изучения Воронежского края в археологическом отношении»; Прозрителев Г. Н. «К вопросу об изучении маджарских древностей», «Археологическим обществам и ученым архивным комиссиям. Об охране памятников старины» и другие);

в) составлением учебных программ для занятий археологией (Соболевский А. И. «Тверские археологические курсы»);

г) составлением археологических карт, чертежей (Пареный М. К. «О серебряном сосуде из Мастюгинского кургана с приложением чертежа», Прозрителев Г. Н. «Остатки древних времен в Ставрополе: Археологическая карта Ставрополя», Языков В. Д. «Могильник на Лысой горе. Чертеж» и другие);

д) деятельностью по сохранению археологических памятников;

е) просветительской деятельностью в области археологии (экспонирование материалов раскопок в музеях).

Деятельность комиссии в этом направлении оказала значительное влияние на создание в регионах обстановки, благоприятствующей охране и изучению археологических памятников, дала толчок к переходу ученых на более высокий уровень исследований, заложила фундамент, на котором в дальнейшем развивались представления о древнейшей истории регионов.

\section{4. Этнография}

Важное место в своих изысканиях сотрудники ГУАК отводили разработке этнографического материала, в первую очередь, для того, чтобы выяснить, кто были древние «насельники» края (Рязанова Е. И. «Материалы по этнографоии Курской губернии»; Магницкий В. К. "К истории "присурских" чуваш, черемис, мордвы и Фролищевой пустыни» и другие). Интересны работы исследователей, посвященные чертам быта, традиционной культуре, этногенезу различных народностей (Фарфоровский С. В. "Социальный состав калмыков»; Ермоленко М. «Предание о кабардинцах Северного Кавказа»; Прозрителев Г. Н. "Гибнущий народ. Туркмены, Инауии. Этнографрический очерк» и другие). Членом Ставропольской ГУАК Прозрителевым Г Н. в работе «Этнографический очерк Ставропольской губернии и Северного Кавказа» была сделана попытка нарисовать общую этническую карту региона. Кроме того, методично проводилась популяризация этнографических изысканий (Зайковский Б. В. «Собирайте русскую бытовую старину!»; Прозрителев Г. Н. «Неотложная задача» и другие).

Отдельно упомянем исследование члена Полтавской ГУАК Л. П. Падалки «Что сказало население Полтавской губернии о своем старом быте», проведенное на основе анкетирования населения губернии. В нем представлено знание «добровольных корреспондентов» из 300 с лишним населенных пунктов в пределах губернии об имени народа, племенном составе населения, жилище, одежде, обрядах и обычаях, языке и песнях Полтавской губернии, а также мнение корреспон- 
дентов об изменениях в народном быте. В работу также вошли выдержки из подлинных сообщений корреспондентов

\section{5. Фольклор}

В рамках этнограффических исследований члены ГУАК обращались к народному творчеству, фольклору. Фольклор как простонародный вид синкретичного творчества, как совокупность «вербальных и вербально-невербальных структур, функционирующих в быту» [15] отображает особый тип мышления, особую систему представлений о мире, он создает «как бы свой мир, не имеющий прямых аналогий в действительности» [15], поэтому также представляет широкий исследовательский интерес.

Сотрудники комиссий интересовались народными обрядами (Смирнов А. В. «Похороны Костромы»; Соболев А. Н. «Обряд прощания с землей пред исповедью, заговоры и духовные стихи» и другие), предметами быта (Поликарпов Ф. И. «Женская крестьянская одежда в с. Истобном, Нижнедевицкого уезда», Соболев А. H. "В чем были погребаемы наши предки-христиане? » и другие), и другими фольклорными памятниками - легендами (Прозрителев Г. Н. «Легенда о происхождении реки Томузлова Ставропольской губернии Александровского уезда», Нориов А. Н. "Легенда о монахине Анне» и другие), преданиями (Ларин Н. «Предания об атамане Барыке», Аносриев Г. В. "Алексин (Местные предания)» и другие), народными (Кудрявцев "Народные песни Липецкого и Усманского уездов», Соколов М. Е. «Великорусские песни» и другие) и историческими песнями (Прозрителев Г. Н. «Песня Стеньки Разина», Соколов М. Е. "Исторические песни Саратовской губернии» и другие), детскими песнями (Минх А. А. "Свадебные, хороводные и друаие песни Полчаниновской волости Саратовского уезда», Рязанова Е. И. "Детские игры, Сороки и другие обычаи» и другие), заговорами (Блохин С. А. «Заговоры», Введенский С. Н. «Из истории волшебства и суеверий в Тамбовском крае» и другие), частушками (Косаткина Е. Г. "Частуики»).

Фольклорные изыскания работников ГУАК образец сочетания научного, публицистического и художественного подходов к изучению и осмыслению фольклорных памятников

\section{6. Музееведение}

Дискурсивная деятельность сотрудников ГУАК связана также и с теорией и методикой музейного дела, важны и практические достижения в этой copepe.

Музеи в большей части губерний стали предметом особого внимания со стороны комиссий. Их устройство было важнейшим направлением деятельностИ ГУАК.

Председатель императорского Археологического института отмечал, что музей, созданный при поддержке Тверской ГУАК, «исторический, промышленный и статистический, уже известен всей России: его посещают не только занимающиеся древностями, но и простолюдины<... >е десятками, а нередко сотнями в один день" [4] а один из членов Тверской ГУАК, Семевский М. И., внес предложение о расширении промышленного отдела в музее и о собирании в музее портретов, автографов и трудов лиц, родившихся в Тверской губернии, что в последствие стало закономерностью для большинства ученых архивных комиссий.

Для создания музея в Нижнем Новгороде члены Нижегородской ГУАК решили организовать прием различных предметов древности от населения, а кроме того, проводить историко-археологические экскурсии. Подобным же образом Саратовской ГУАК удалось собрать для губернского музея 3 тысячи предметов древности, нумизматики, палеографии .

Главным разработчиком музея в Ставропольской губернии стал Прозрителев Г Н. Основанный музей, по словам Колесниковой М. Е., имел «всеобъемлющий краеведческий характер, осуществлял большую научно-исследовательскую собирательскую и просветительскую работу, являлся по сути центром науки и культуры края» [2, c. 336].

Сохранились исследования членов ГУАК, посвященные:

а) выработке приемов музейного экспонирования предметов (Сераиев С. И. «Археологический отдел Пермского музея», Прозрителев Г. Н. «Кавказский музей» и другие);

б) определению методики составления музейного каталога («Каталоа исторической юбилейной выставки в память 250-летия Симбирска»)

в) решению вопросов административной и научной организации музея (Абаза М. М. «К вопросу о пополнении музыкального отдела в Курском историко-археологическом музее», Щеглов С. А. «Историко-археологический музей в 1914 году» и другие);

г) описанию музейных экспонатов (Минх A. A. "Ценное приобретение нашего музея», Добровольский П. М. "Описание исторического музея Черниговской ГУАК. Церковные древности и предметы христианского культа; Исторический отдел: быт военный и домашний» и другие).

При этом каждая из комиссий при организации музея ставила своей целью «распространение исторических знаний вообще и в пределах местно-областной истории, в особенности среди местного общества» [4]

7. Биографические исследования

В область задач биографа входит познание и реконструкция «личности в ее становлении и развитии» $[13$, с. 77], а ведущей жанровой особенностью биографии является «стремление третьего лица воссоздать словесными средствами целостный процесс становления, развития и деятельности исторической личности» [13, с. 23]. Интересен тот фракт, что биографию, по мнению К. Бруммак, нельзя причислить ни к одному из родов литературы, так как она может быть написана в любом из них, кроме того, дополнительной сложностью является существование многочисленных биограсрических форм. 
Однако данные особенности не помешали Г. О. Винокуру включить биографию в список самостоятельных научных дисциплин историко-фрилологической парадигмы: «По своим методам и приемам биография примыкает к филологии, поскольку овладение источниками биографии возможно лишь путем интерпретации исторических памятников» [1, с. 12].

Число биографических исследований сотрудников ГУАК внушительно. Ученые обращались к деталям биографий крупных исторических лиц

а) правителей и членов их семьи (Александр II, Петр I, великий князь Георгий Всеволодович, Евдокия Лопухина);

б) предводителей восстаний (Емельян Пугачев, И. М. Мазепа, Имам Шамиль, П. П. Шмидт);

в) политических деятелей (М. М. Сперанский А. Г. Розенберг, Г. С. Волконский, Г. А. Лопатин);

г) деятелей искусства (Н.В.Гоголь, Л.Н.Толстой, И. С. Тургенев, М. Е. Салтыков-Щедрин И. И. Лажечников, В. В. Капнист, А. Н. Радищев C. Тончи);

д) общественных деятелей (Е. Переяславский, Л. С. Голицын, Шейх Мансур).

Однако сохранилось гораздо больше биографических исследований, посвященных личностям, известным только в масштабах губерний Это биографии, автобиографии, жития, некрологи и воспоминания:

а) сотрудников ГУАК (Г Н. Прозрителев Г. А. Залюбовский, Поль А. Н., Новицкий Я. П. М. М. Шуцкий, В. И. Снежневский и другие);

б) региональных служителей церкви (протоиерей К. Павловский, протоиерей И. И. Базаров, епископ Феодосий, епископ Евлампий, архиепископ Ириней и другие)

в) региональных ученых (исследователь Кавказа Н. Я. Динник, этнограф Закревский, историк, этнограф И. И. Манжура, историк И. Д. Попко, географ, натуралист Г И. Радле, археолог П. Г. Беляев и другие);

г) губернских писателей (писатель-фольклорист Маркевич Н. А., писатель-этнограф В. А. Сбоев, писатель-беллетрист С. Н. Миловский (Елеонский), писатель-путешественник Е. Л. Марков, поэт И. С. Никитин, поэт И. П. Катляревский и другие);

д) региональных государственных и общественных деятелей (секретарь статистического комитета И. В. Бентковский, частный поверенный 3. Ф. Будаш-Будашевский, сестра милосердия Р. М. Иванова, князь Киприани, князь М. С. Воронцов, генерал Н. С. Заводовский, рецензент Екатиринослвасского театра Мизко Д. Т., кошевой А. И. Кальнишевский, майор А. Кучевский, граф М. Н. Муравьев-Виленский, чиновник Нижегородского собора Пушников, генерал-губернатор Н. П. Игнатьев, судья Ромашев и другие)

Кроме того, сотрудниками ГУАК составлялись словари и списки «замечательных деятелей региона», например, «Библиографический словарь писателей и ученых Рязанского края», «Список замечательных лиц, родившихся в Тамбовской губернии» и другие, а также библиографические списки литературы, посвященной видным деятелям губерний («Библиографические указания о П. У. Белякове», «Указатель статей о губернаторе А. Д. Панчулидзеве» и другие).

\section{8. Экономика}

Уже в начале XX века обнаружился внутренний кризис ГУАК, связанный с массовой публикацией исторических источников вместо научных изысканий. Он грозил утратой «научности», возвратом к архивной описательности и «пережевыванию» публикуемых источников» [4]. Подобная ситуация требовала перехода к проблемным исследованиям, в частности к социально-экономической проблематике.

Основные проблемы данной области, интересовавшие ученых, затрагивали вопросы установления и организации торговых отношений (Прозрителев Г. Н. «Местная хроника $Г О$ ходе торговли на Троицкой ярмарке города Ставрополя]», Сташевский Е. А. "Заметка о торговле Нижнего Новгорода в первой половине XVII века», Звездин А. И. "О продаже людей на Нижегородской ярмарке» и другие), ценопроизводства (Прозрителев Г. Н. «Рост чен на продукты в Ставрополе-губернском», Белоцерковский Г. М. "Справка о ценах ржи и овцса в Дедилове, Крапивне и Михайлове» и другие), разработки природных ресурсов (Прозрителев Г. Н. «К вопросу о нефтти в Ставрополье»), экономики сельского хозяйства (Прозрителев Г. Н. «Шелководство в Ставропольской әубернии») и производства (Пульхеров А. И. "О причинах упадка и закрытия Брынского и Есенковского чугунолитейных и железоделательных заводов»); исследовались также особенности землевладения в регионах в пореформенную и послереформенную эпохи (Снежневский В. И. "Новая оценка земли в Нuжегородском уезде и вызываемые ею недоразумения», "Генеральное межевание земель и несколько сведений о характере землевладения в Нижегородском крае» и другие)

Важной темой для исследователей стали реформы 60-Х гг. XIX В. (Драницын Н. И. «700-тысячная растрата в Нижегородском казначействе», Савельев А. А. "Три проекта об улучшении быта крепостных крестьян в Нижегородском уезде», Тихомиров И. Ф. «Строгая ревизия (эпизод из калужской жизни начала XIX столетия)» и другие). Ученые отмечали неподготовленность их осуществления, отрицательное влияние на российскую экономику государственного контроля, а также трудности ведения крестьянского хозяйства на новых основаниях.

\section{9. Филология}

Научное творчество членов ГУАК отражает внимание исследователей к языковым и речевым явлениям, а также их собственную лингвистическую и литературоведческую работу. Среди действительных членов ГУАК числились как профессиональные филологи (А.А. Шахматов, член Саратовской ГУАК, Д. К. Зеленин, член Вятской ГУАК, Д. И. Яворницкий, член Екатеринославской ГУАК, и другие), так и известные писатели (Е. А. Марков, И.С. Никитин). 
В своих лингвистических изысканиях члены комиссии охватывают в основном лексический пласт языковой системы, что связано с интересом к этимологии тех или иных топонимов региона. В пределах этой проблематики представлены малые научные работы, по большей части отдельные статьи (Е. Исполатов «О происхождении некоторых географических названий Псковской әубернии», Л. В. Падалка "Происхождение и значение имени "Русь"», Ф. П. Саваренский "О географических названиях Тульской губернии», С. Березнеговский "Замечания о названии г. Кадома» и другие).

В рамках анализа этнографических данных исследователи обращаются к фонетическому уровню языка, в частности к верной фонетической записи диалектного материала (M. Е. Coколов «Фонетическая запись сказки об Илье Муромце», "Великорусские песни, записанные фонетически» и другие), для чего академиком А. И. Соболевским, членом Тверской ГУАК, была разработана программа собирания сведений о народных говорах.

Кроме того, находим примеры комплексного лингвистического анализа фольклорных текстов (M. Е. Соколов «О языке сказок, песен и областных словарях» и другие), а также опыты перевода надписей на археологических памятниках (В. К. Туравской "Надаробные надписи из текии Афраан Мохаммед-Султана в 2. Касимове» и другие).

Литературоведческие изыскания посвящены:

а) анализу творчества отдельных писателей, как общеизвестных, так и региональных (B. Беднов «K характеристике местных литературных нравов (C. А. Никитин и его "Eкатеринославская старина"), Н. Быков "Народная душа в творениях Т Г. Шевченко», Д. И. Яворницкий «Запорожцы в поэзии Т Г. Шевченко», А. Д. Фадеев «С. Н. Марин и его литературные произведения», С. В. Фарфоровский «Литературная деятельность Попко» и другие);

б) анализу отдельных художественных произведений (А. М. Путинцев "Вопрос о тексте поэмы "Тарас"», А. В. Смирнов "Литературные опыты воспитанников Владимирской духовной семинарии в начале XIX столетия», М. И. Капустин «Поэзия и проза в старой Пермской Семинарии», А. Д. Фадеев "Сmuхотворение С. Н. Марина» и другие);

в) сбору историко-литературных материалов об отдельных авторах (А. М. Путинцев «Новые письма И. С. Никитина», "По повожу желаемых улучшений в издании сочинений И. С. Никитина», М. Н. Былов «Сообщение по поводу неизданных писем поэта И. С. Никитина», Г. Н. Прозрителев «Память о Н. В. Гоголе в захолустьях Полтавской аубернии», И. С. Шукиинцев "Из неизданных произеедений Державина», И. Ф. Павловский "О распространении в Малороссии произведения Шевченко» и другие).

10. Не так комплексно и подробно, но с определенным интересом уделяли внимание ученые таким областям знания, как: а) искусствоведение: сохранились работы, содержащие анализ живописи и скульптуры (Геораиевский В. $T$ «Новый взаляд на памятники искусства Владимиро-Суздальской области домонгольского периода», Четыркин И. Д. «Замысловатое изображение» и другие), архитектурных памятников (Четыркин И. Д. «Деревянные резные трехстворчатые складни ХVII столетия», Слупский А. И. «К вопросу о московском и новгородском влияниях в архитектурных памятниках Соликамска и Чердыни» и другие), иконографии (Четыркин И. Д. "Иконографические формы Се. Великомученика Никиты Готского и объяснение значения этих изображений», Первухин Н. "О символизме в старой русской иконописи» и другие).

б) философия: представлены тексты, содержащие собственные философские размышления ученых (Прозрителев Г. Н. «Заметки. Моя личная фолософия. История борьбы с Богом»), а также тексты, исследующие проблему генезиса философии (Леонтовский В. П. «Полтавский мыслитель-поэт Г. С. Сковорода и генезис его философьии»); несколько трудов посвящены анализу филлософрских произведений (Леонтовский В. П. "К тексту "Змий Израильский"» и другие).

в) география: находим рукописи, посвященные описанию и локализации рек и гор регионов (Кобылин А. Н. «Несколько ведений о реках Курской области», Орлов А. Н. "Истоки рек Оки, Свалы, Сновы и Сновки», "Лысая гора, Крутой яр и Каниевское» и другие), характеристике географической оболочки губернии, ее климата (Прозрителев Г. Н. «Оползни в бывшей Ставропольской әубернии», "Сыпучие пески в Ставропольской әубернии» и другие).

г) агрономия: сохранились работы о выращивании овощных и плодовых культур в регионе (Прозрителев Г. Н. «Тыква»), о мерах борьбы с вредителями (Прозрителев Г. Н. «Историческая справка о мерах борьбы с саранчою в Ставропольской губернии»), о качестве и количестве земель губернии (Модзалевский В. Л. «Пространство губернии по межевым документам. Число дач, полос и участков»), их межевании (Василенко В. И. «К истории размежевания земель в Полтавской губерниия).

д)медицина:уцелелитруды, описывающиеианализирующие народную медицину (Овчинников $M$. «Материалы по народной медицине»), эпидемии (Алелеков А. Н. «Психопатическая эпидемия в с. Никулине Нижегородской губернии», Несвицкий А. А. "Чума. Мероприятия против заноса чумной заразы в Полтавскую губернию в XIX веке» и другие), психические расстройства (Звездин A. И. "О кликушестве в XVII-XVIII вв.»).

е) палеонтология: сохранились работы, содержащие описание раскопок (Данилевич В. E. "OMчет о раскопках Курской ученой архивной комиссии в Курском уезде в мае и июне 1907 года», Сосновский К. П. "Дневник раскопок в овраге Волчий-Верх близ д. Плоховки, Никитинской волости, Щиаровского уезда, произведенных 
К. П. Сосновским 16 и 17 июля 1910 года» и друаие) и палеонтологических находок (Четыркин И. Д. "Открытие в Козельском уезде Калужской губернии близ деревни Стенино остатков палеолитической эпохи», Каншин В. П. «Умрихинский мамонт и следы человека палеолитической эпохи» и другие), а также лекции по палеонтологии (Прозрителев Г. Н. «Лекции по палеонтологии»).

ж) кроме того, нами найдена одна работа по астрономии, посвященная описанию солнечного затмения, и одна работа по химии, знакомящая с химическим анализом древнего зеркала.

Научные тексты сотрудников комиссии отличаются логичностью и последовательностью изложения, фактологичностью и высокой степенью обобщенности; авторы включают в них ссылки на архивные и другие научные источники, а также целые цитаты из этих источников, что позволяет говорить об интертекстуальности

II. Вовлеченность членов ГУАК в педагогическую деятельность в большей степени связана c желанием «выработать у народа сознательное и деятельное отношение к историческому опыту, привить любовь к родному краю и его древностям» [4]. Ученые старались дать практическое применение результатам своих научных изысканий, донести их до каждого желающего. В связи с этим многие члены комиссий читали лекции и вели специальные курсы, которые имели среди слушающих «выдающийся успех».

Так, 1912 году в Твери были организованы археологические курсы, в рамках которых читались лекции по русской истории со времен Владимиро-Суздальской Руси до времени правления Алексея Михайловича, лекции по древней русской литературе, по русской палеографии, по истории русского церковного зодчества, скульптуры и иконописи.

Председатель Ставропольской ГУАК Прозрителев Г. Н. преподавал в духовной семинарии французский язык, математику, физику, а позже в педагогическом техникуме читал лекции по сельскому хозяйству, ветеринарии, археологии, этнографии, палеонтологии и краеведению, в основу которых легли его собственные исследования.

Многие члены комиссий были профессиональными педагогами, преподавателями университетов, реальных училищ, гимназий, школ.

Среди трудов ученых комиссий сохранились

а) лекции по палеонтологии (Г. Н. Прозрителев «Лекции по палеонтологии»), по генеалогии ("Лекции по русской генеалогии, читанные в Московском археологическом институте преподавателем института Л. М. Савеловым»), по истории (Прозрителев Г. Н. «Программа лекций о событиях 1905 г. в Ставропольской губернии»);

б) программы по собиранию говоров, по собиранию сведений о первобытных и исторических древностях, для собирания этнографических предметов, по изучению региона (Г. Н. Прозрителев «Программа изучения Ставропольского края. Ведение краеведческой работы»); в) учебно-методические пособия (Г. Н. Прозрителев «Краткий курс краеведения. Ставропольская ауберния», "Пособие по изучению Саратовского края», Л. М. Попова «Историко-археологические курсы Тверской Губернской Ученой Архивной Комиссии»).

III. Основной профессий многих членов комиссий была юриспруденция. Юридические работники-члены ГУАК - это прокуроры, нотариусы, мировые и городские судьи, адвокаты, судебные чиновники, следователи и присяжные поверенные.

В основе своей в юридических изысканиях членов комиссий вопросы правосудия прямо соотносятся с действительностью и активно взаимодействуют с другими дискурсивными сферами. Именно в систематическом накоплении повседневных бытовых и юридических черт, которые смогли бы воссоздать картину ушедшей жизни, видели свою задачу исследователи. Ученым принадлежат работы публицистического характера, в которых они анализируют уголовные преступления (Кашкаров В. М. «Дело о разграблении усадьбы Домогацкого», Звездин А. И. «Криминальное дело», Коневский М. Ф. "Дело балахинского уездного суда по указу Нижегородской уголовной палаты о священнике Кондакове» и другие), дела мирового суда (Прозрителев Г. Н. «Дела и правы [О делах, рассматривавшихся на заседаниях съезда и камерах городских судей]»), финансовые дела (Снежневский В. И. Спорное дело об аренде мельницы на р. Сереж, под д. Вторускою, Терюшевской волости», Вишневский И. И. "Сыскное дело Арзамасской приказной избы о краже денеа и имущества в Арзамасе у черного попа Троицкого монастыря Варсонофия» и другие), дела по земельному праву (Харизоменов С. А. «Материалы по четвертному землевладению Саратовской губернии», Падалка Л. "О происхождении и особенностях владения казачьими наследственными землями в Малороссии» и другие), поднимают вопросы законотворчества (Снежневский В. И. «Новый избирательный закон и выборы землевладельцев»).

Одна из работ председателя Ставропольской ГУАК Г. Н. Прозрителева может характеризоваться как монография по юриспруденции, так как дает комплексный обзор и анализ юридической деятельности в регионе (Прозрителев Г. Н. «Кто ответчик за смерть от деяния, самого по себе безразличного?»)

IV. ГУАК вели активное сотрудничество с органами печати. Нижегородская ГУАК, например, поддерживала связь с журналами и газетами: «Голос минувшего», «Ежегодник императорских театров», «Журнал Министерства народного просвещения», «Исторический вестник», «Новое времЯ», «Русский архив», «Русская старина», «Русские Ведомости», «Русская мысль», «Вестник Европы» и другие. Как отмечает Макарихин В. П., редакции печатных изданий в полной мере «содействовали деятельности провинциальных обществ», иногда высылая «свои труды им за полцены» [4]. 
Некоторые члены ГУАК становились инициаторами создания региональных газет, так председатель Ставропольской ГУАК Г Н. Прозрителев выступил с проектом создания газеты «Северный Кавказ», задачи которой были подчинены «социально-политическому, экономическому, правовому, культурному просвещению читательской аудитории» [3, с. 37].

Функция воздействия публицистического текстового поля ГУАК определяется призывностью (побудительный характер речи), речевой выразительностью (средства словесной образности), собирательностью (обобщенные фрормы первого и третьего лица, частое употребление местоимений «мы», «наш»), простотой и доступностью. Информативность текстов сопряжена с достоверностью, объективностью и фактологичностью.

Публицистические тексты членов комиссий характеризуются тематической разнородностью и жанровой гетерогенностью: рецензии и отзывы на печатные издания, разборы отдельных сочинений (С. И. Архангельский «Разбор сочинения Адама Шлейссинга "Описание Московского государства в царствование Петра / и Иоанна с прибавлением описания Сибири"», В. П. Соколов "Отзыв о "Записке Якубовского»", Библиографический отзыв об издании "Материалы для истории Владимирской аубернии" А. В. Смирнова" и другие); археологические хроники (И. Д. Четыркин "Археологическая выставка в Киеве», Н. В. Теплов "Открытие в Фивах аробницы Тутмеса II/» и другие); хроники общественной жизни губерни и (П. Мартынов «Празднование двухсот пятидесяти летнеао юбилея города Симбирска», Н. М. Ликин «Основание Катунского приходского училища и торжественное открытие его 27 сентября 1814 года», В. Пархоменко «Тысячелетие города Переяслава», «Пуикинские дни в Оренбурге» и другие); статьи, посвященные внешней политике России и ее внутренней социально-политической ситуации (С. Н. Вагин «Пример злоупотребления "словом и делом»), а также юридическим (В. И. Снежневский «Новый избирательный закон в Нижегородском уезде и выборы земледельцев»), экономическим (С. Березнеговский "Ответ на статью г. Сушина о невыгоде направления линии Саратовской железной дороаи на Тамбов», В. И. Снежневский "Денежное хозяйство Нижегородского уездного земства за 1902 год», "Новая оценка земли в Нижегородском уезде и вызываемые ею недоразумения» и другие), хозяйственным (И. Ф. Пав- ленко «К вопросу о переводе Ильинской ярмарки из Ромен в Полтаву», В. И. Снежневский «Возможна ли у нас китайская культура хлебов?», А. А. Савельев «Три проекта об улучшении быта крепостных крестьян в Нижегородском уезде», В. И. Снежневский «Почему мы не слышим земцев в деревне» и другие) проблемам региона; научно-популярные статьи $(B . И$. Снежневский "Старый нижегородский театр», Б. В. Зайковский «Собирайте русскую бытовую старину!»); путевые очерки (П. Н. Боев "Поездка в Зубриловку в 1912 году», А. Н. Минх «Путевые заметки от Москвы до села Колепа 1869 г.» и другие); проблемные очерки (Ф. П. Коновалов «Борьба с сектантством в Балашовском уезде», В. В. Косаткин «О бородачах и раскольниках, чтоб за бороду пошлину платили и в указанном платье ходили», Д. Мордовцев «Люди, их слова и дела» и другие); очерки деятельности комиссий («Очерк деятельности Пермской ученой архивной комиссии за 1891 и 1892 годы» и другие); некрологи (А. Ф. Мальцев «Г. П. Алексеев», Н. Н. Новиков "Памяти А.А. Дмитриева» и другие); заметки (И. Д. Четыркин «Замысловатое изображение», "Расписной валек», "Складни», Е. С. Филимонов "Что такое тептяри? Беглая заметка» и другие); воспоминания, записки, впечатления (П. Бахметьев "Освобождение моего отиа от крелостного ига», Б. Зайковский «Впечатления из поездки в Елань-Аткарскую», С. Щеалов «Город Петровск. Отрывки из воспоминаний», "Записки сторожила Ивана Ивановича Исаева о городе Ельце» и другие); интервью (Л. В. Падалка "Что сказало население Полтавской губернии о своем старом быте»).

Сложно определить жанровую принадлежность некоторых публицистических работ членов комиссий, так как многие из них обладают жанровым синкретизмом, сложной структурой, полифункциональностью и многозначностью.

Подобный масштаб исследовательской деятельности и объем достижений в различных областях науки и общественной жизни говорит об уникальном стиле мышления сотрудников комиссий, владении систематизированным, цельным, разносторонним, интегрированным знанием различных областей фундаментальной и прикладной науки, а также о способности объективно оценивать содержание знания, обладая компетенцией усваивать и выражать его сквозь призму разных видов дискурса.

\section{Литература}

1. Винокур Г. О. Биография как научная проблема (тезисы доклада) // Биография и культура. Русское сценическое произношение. М.: Русские словари, 1997. С.11-88.

2. Колесникова М. Е. Исследовательская деятельность Ставропольской ученой архивной комиссии как раннепрофессиональная коммуникативная практика провинциального интеллектуального сообщества первой четверти XX века // Язык и текст в пространстве культуры: Сб. статей науч.-методического семинара “TEXTUS». Вып.9. Спб; Ставрополь: СГУ, 2003. С.328-340.

3. Лепилкина О. И. “Северный Кавказ» (1884-1906) - первая частная газета на Ставрополье // Лепилкина О. И. История ставропольской журналистики: Учебное пособие и хрестоматия. Ставрополь: СГУ, 2005. С.31-42.

4. Макарихин В. П. Губернские ученые архивные комиссии России: монография. Нижний Новгород: Волго-Вятское книжное изд-во, 1991. URL: http://www.opentextnn.ru/history/historiografy/institut/?id=947 (Дата обращения: 14.06.2019) 
5. Малышева Е. Г. Русский спортивный дискурс: теория и методология лингвокогнитивного исследования: дис. .. д-ра филол. наук. Омск, 2011. 402 с.

6. Манаенко Г. Н. Лингвистические координаты понятия «дискурс» // Вопросы когнитивной лингвистики. 2011. №4 (029). C.83-92.

7. Монгайт А. Л. Рязанская земля. М.: АН СССР, 1961. 400 С.

8. Официальные документы по учреждению ученых архивных комиссий и губернских исторических архивов // Вестник археологии и истории. Санкт-Петербург: Типография Императорской Академии наук, 1885. Вып. 1. С.10-15.

9. Проект Положения об исторических архивах и учёных архивных комиссиях // Сборник материалов, относящихся к доархивной части в России. Т.1. Петроград: Издание т-ва А. С. Суворина, 1916.710 с.

10. Ревзина О. Г. Дискурс и дискурсивные формации // Критика и семиотика. Вып. 8. 2005. С.66 - 78.

11. Толстов В. А. Рязанская губернская ученая архивная комиссия: история создания, труды и коллекции: автореферат дис. канд. истор. наук. Саратов, 2003. 23 с.

12. Труды Саратовской ученой архивной комиссии. 1890. Т.3. Вып. 3. Саратов, $1890.300 \mathrm{c}$

13. Холиков А. Биография писателя как жанр: учеб. пособие. М.: «Либроком», 2010. 96 с.

14. Чекурин Л. В. Историческое краеведение, историография и источниковедение: Учеб. пособие. М.: МРИК, 1991 $196 \mathrm{c}$.

15. Чистов К. В. Фольклор // Культурология. XX век: энциклопедия в 2-х т. Спб: Университет, 1998. URL: http://psylib org.ua/ books/levit01/txt107.htm. (Дата обращения: 14.06.2019).

\section{References}

1. Vinokur G. O. Biografija kak nauchnaja problema (tezisy doklada). Biografija i kul'tura. Russkoe scenicheskoe proiznoshenie (Biography as a scientific problem (thesis). Biography and culture. Russian stage pronunciation). Moscow: Russkie slovari, 1997. P.11-88. (In Russian).

2. Kolesnikova M. E. Issledovatel'skaja dejatel'nost' Stavropol'skoj uchenoj arhivnoj komissii kak ranneprofessional'naja kommunikativnaja praktika provincial'nogo intellektual'nogo soobshhestva pervoj chetverti XX veka (Research activity of the Stavropol scientific archive commission as early professional communicative practice of the provincial intellectual community of the first quarter of the XX century) // Jazyk i tekst v prostranstve kul'tury. Issuw.9. St.Petersburg; Stavropol': SSU publ., 2003. P.328-340. (In Russian).

3. Lepilkina O. I. «Severnyj Kavkaz» (1884-1906) - pervaja chastnaja gazeta na Stavropol'. Istorija stavropol'skoj zhurnalistiki: Uchebnoe posobie i hrestomatija ("North Caucasus" (1884-1906) - the first private newspaper in the Stavropol region. History of Stavropol journalism: Textbook and anthology). Stavropol': SSU publ., 2005. P.31-42. (In Russian).

4. Makarihin V. P. Gubernskie uchenye arhivnye komissii Rossii: monografija (Provincial scientific archival commission of Russia: monograph) URL: http://www.opentextnn.ru/history/historiografy/institut/?id=947. (Accessed: 14.06.2019). (In Russian).

5. Malysheva E. G. Russkij sportivnyj diskurs: teorija i metodologija lingvokognitivnogo issledovanija (Russian sports discourse: theory and methodology of linguocognitive research): thesis. Omsk, 2011. 402 p. (In Russian).

6. Manaenko G. N. Lingvisticheskie koordinaty ponjatija "diskurs» (Linguistic coordinates of the concept "discourse") // Voprosy kognitivnoj lingvistiki. 2011. No.4 (029). P.83-92. (In Russian).

7. Mongajt A. L. Rjazanskaja zemlja (Ryazan land). Moscow: SA USSR publ., 1961. 400 p. (In Russian).

8. Oficial'nye dokumenty po uchrezhdeniju uchenyh arhivnyh komissij $i$ gubernskih istoricheskih arhivov (Official documents on the establishment of scientific archival commissions and provincial historical archives) // Vestnik arheologii $\mathrm{i}$ istorii. St.Peterburg: Tipografija Imperatorskoj Akademii nauk, 1885. Isue. 1. P.10-15. (In Russian).

9. Sbornik materialov, otnosjashhihsja $\mathrm{k}$ doarhivnoj chasti v Rossii (A set of materials related to pre-archival part in Russia). Vol.1. Petrograd, 1916. p. 710. (In Russian).

10. Revzina O. G. Diskurs i diskursivnye formacii (Discourse and discursive formations). Kritika i semiotika. Issue. 8. 2005. P.66-78. (In Russian).

11. Tolstov V. A. Rjazanskaja gubernskaja uchenaja arhivnaja komissija: istorija sozdanija, trudy i kollekcii (Ryazan provincial scientific archive commission: history of creation, works and collections): abstract of thesis. Saratov, 2003. $23 \mathrm{p}$. (In Russian)

12. Trudy Saratovskoj uchenoj arhivnoj komissii (The works of Saratov scientific archive comission). Vol. 3. Issue. 3 Saratov, 1890. 300 p. (In Russian).

13. Holikov A. Biografija pisatelja kak zhanr (Biography of the writer as a genre). Moscow: Librokom, 2010. 96 p. (In Russian).

14. Chekurin L. B. Istoricheskoe kraevedenie, istoriografija i istochnikovedenie (Historical local history, historiography and source studies). Moscoe: MRIK, 1991. 196 p. (In Russian).

15. Chistov K. V. Fol'klor (Folklore) // Kul'turologija. XX vek: jenciklopedija v 2-h t. URL: http://psylib.org.ua/ books/levit01/ txt107.htm. (Accessed: 14.06.2019). (In Russian).

\section{Информация об авторе}

Минина Александра Ивановна - аспирант кафедры русского языка гуманитарного института Северо-Кавказского федерального университета (Ставрополь) / Marmoduk@gmail.com

\section{Information about the author}

Minina Aleksandra - postgraduate, Chair of Russian Language, Institute of Humanities, North-Caucasus Federal University (Stavropol) / Marmoduk@gmail.com 